\title{
Limnological variations of a reservoir during two successive years: One wet, another dry
}

\author{
A. M. Geraldes ${ }^{1}$ and M. J. L. Boavida ${ }^{2 *}$ \\ ${ }^{1}$ CIMO, Escola Superior Agrária de Bragança, Campus de Santa Apolónia, Bragança, Portugal, and ${ }^{2}$ Centro de \\ Biologia Ambiental, Departamento de Biologia Animal, Faculdade de Ciências da Universidade de Lisboa, \\ Campo Grande, Lisbon, Portugal
}

\begin{abstract}
Changes in environmental variables, as well as in planktonic algae and in crustacean zooplankton abundance, were investigated in a meso-eutrophic reservoir during two successive years: one wet, another dry. In the wet winter, both total phosphorus and soluble reactive phosphorus reached their maxima, whereas water transparency achieved the minimum during the same period. The obtained data suggest that total phosphorus and soluble reactive phosphorus peaks were related to the increase in nutrient loading as a consequence of the intense rainfall which occurred during this period. Phytoplankton composition was dominated by Cyclotella spp., except during the dry winter when Anabaena became dominant. The dominance of this alga seemed to be related to nitrate depletion. The establishment of more stable environmental conditions (e.g. low water turbulence, longer water retention time) and the increase of irradiance during the dry period (summer 2001 and winter 2001/2002) also favoured growth of this cyanobacterium. Concomitant to Anabaena dominance, Ceriodaphnia abundance decreased while nauplii increased. Although variation between the two years of study seemed to be related to the sequence of a pluvial and a dry year, further research is needed to evaluate whether variations in precipitation intensity influence reservoir ecological processes.
\end{abstract}

\section{Key words}

crustacean zooplankton, dry years, nutrients, phytoplankton, reservoir, wet years.

\section{INTRODUCTION}

Seasonal events, such as precipitation, are among the most important factors influencing aquatic systems in the Mediterranean region. Both the intensity and quantity of the rainfall, however, can vary markedly from one year to another at these latitudes. The temperature fluctuates in a narrow range, although this parameter is generally slightly higher in wet winters than in dry winters. Such variability can generate different kinds of seasonal patterns, modifying water turnover time and changing the intensity of environmental and biological processes occurring in the water column (Catalan \& Fee 1994; Armengol et al. 1999). Furthermore, the external loading of nutrients, organic matter and pollutants often increases with intensive precipitation events. In addition, the input of materials into a water body at the beginning of a rainfall event is higher than

*Corresponding author. Email: mjboavida@fc.ul.pt

Accepted for publication 27 April 2004. the input generated at the end of the event (Barbosa \& Hvitved-Jacobsen 1999). The intensity and the magnitude of these inputs, however, depend on such factors as land use, vegetation cover and landscape patchiness (Rybak 2000).

Azibo Reservoir is located in the Iberian Peninsula on the Portuguese part of the international Douro River drainage basin. In this region, most precipitation occurs between October and March in a very irregular pattern from one year to another (Fig. 1). The total annual precipitation varies between 800 and $1000 \mathrm{~mm}$, with the 'normal' autumn/winter season total precipitation being $\approx 630 \mathrm{~mm}$. In contrast to other reservoirs in the region, water level fluctuations caused by human activity are not very accentuated in Azibo Reservoir. Thus, this reservoir provides a good environment for studying the potential effects of quantity and intensity of precipitation without the interference of internal disturbances generated by extreme anthropogenic water level fluctuations.

The objective of this study, therefore, was to assess the variations in such water quality parameters as total 
phosphorus (TP), orthophosphate (determined as soluble reactive phosphorus, SRP), nitrate $\left(\mathrm{N}-\mathrm{NO}_{3}\right)$, ammonium

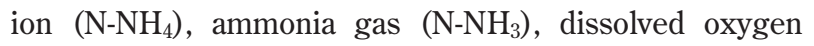
(DO), conductivity, $\mathrm{pH}$ and water transparency during two successive years, one being hydrologically 'wet' and the subsequent one being 'dry.' The variations of biotic attributes such as chlorophyll $a(\operatorname{chl} a)$, phytoplankton and crustacean zooplankton composition or species relative abundance were analysed in a similar manner.

\section{STUDY AREA}

Azibo Reservoir is located in the Portuguese part of the Douro River drainage basin. The area of the reservoir is 410 ha, with a total capacity of $54470 \times 10^{3} \mathrm{~m}^{3}$. The maximum and mean depths are $30 \mathrm{~m}$ and $13.2 \mathrm{~m}$, respectively. The mean water residence time is $\approx 2.2$ years. This reservoir was first filled in 1982, being used mainly for recreation purposes. Other uses include urban water supply and irrigation, although these latter uses are not significant. The water level fluctuations vary between 1.5 and $2 \mathrm{~m}$. In Azibo Reservoir, the direct influence of human activities is larger during summer, when the reservoir and its surroundings are used for recreation (swimming, camping, boating, angling). Activities that take place throughout the year in the drainage basin include farming and grazing. The potential nutrient loads generated by those activities are $\approx 243275 \mathrm{~kg}$ of nitrogen $(\mathrm{N})$ and $116956 \mathrm{~kg}$ of phosphorus (P) per year (Geraldes \& Boavida 2003). During the study period, the thermal stratification of the reservoir occurred between June October and the reservoir was classified as being in a meso-eutrophic condition.

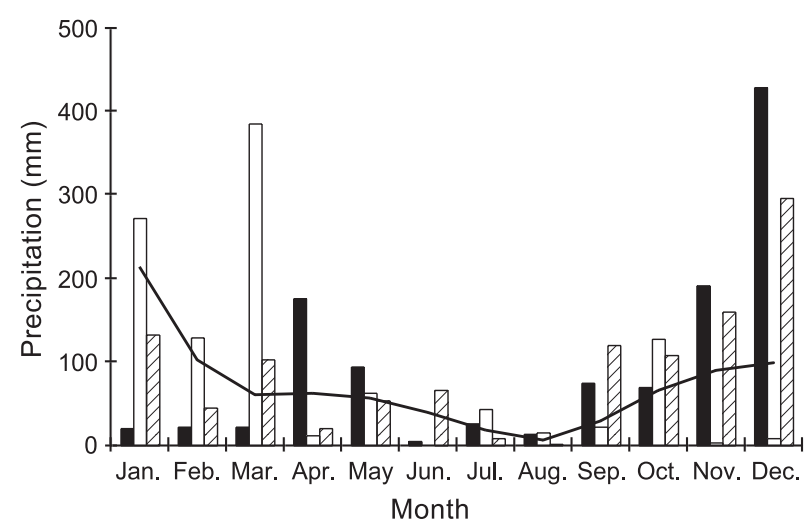

Fig. 1. Precipitation per month between 2000 and 2002 in the largest city close to Azibo Reservoir (Agroclima Lab-ESAB, unpubl. data, 2000-2002) and monthly means based on regional rainfall data from 1960-1990 (Institute of Meteorology-Portugal 2001). 口, 2000; $\square, 2001$; 2002; -, mean value (1960-1990).

\section{METHODS}

Water samples were collected monthly in winter and biweekly in summer from the deepest point of the reservoir during the period October 2000 to September 2002. Samples for determination of SRP, TP, $\mathrm{N}_{-} \mathrm{NO}_{3}, \mathrm{~N}_{-} \mathrm{NH}_{4}$ and $\mathrm{N}-\mathrm{NH}_{3}$ were obtained from the upper $30-40 \mathrm{~cm}$, except during the stratification period, when samples also were drawn from the middle of the water column $(7-10 \mathrm{~m})$ and the bottom layer. For simplification, it was assumed that nutrient concentrations did not change with depth during mixing; thus, samples were taken only from near the surface layer when the reservoir was not stratified. The samples were placed into acid-rinsed bottles and transported to the laboratory in a cold container. The SRP concentration was estimated by the method of Murphy and Riley (1962) and the TP concentration was assessed after acid hydrolysis with persulphate for $60 \mathrm{~min}$ under high temperature and pressure (American Public Health Association 1989). Chlorophyll $a$ samples were obtained from $500-1000 \mathrm{~mL}$ of integrated water samples taken at the euphotic zone and filtered through a GF/A (Whatman, Maidstone, England) filter within $2 \mathrm{~h}$ after their collection. The chlorophyll concentrations were determined spectrophotometrically after overnight extraction in acetone. Environmental variables, including water temperature, DO, conductivity and $\mathrm{pH}$, as well as $\mathrm{N}-\mathrm{NO}_{3}, \mathrm{~N}_{-} \mathrm{NH}_{4}$ and $\mathrm{N}-\mathrm{NH}_{3}$, were measured in situ with a 6820 YSI multiparameter water quality monitor (Yellow Spring Instruments, Ohio, USA). The water transparency was measured with a 20-cm diameter black and white Secchi disk.

Zooplankton samples were obtained on each sampling date by taking two vertical hauls, using a Wisconsin-type net of $64-\mu \mathrm{m}$ mesh size made by the School's maintenance services. Zooplankton were anaesthetized with carbonated water and preserved in sugar-saturated formaldehyde (4\% final concentration). Depending on the density, the zooplankton were counted in 5,10 or $20 \mathrm{~mL}$ subsamples, or in the whole water sample. The organisms were identified down to the species level, based on the methods of Scourfield and Harding (1966) and Dussart (1969). Integrated water samples were collected from the euphotic zone for phytoplankton analyses. The samples were fixed in situ in Lugol's solution (V. Reis, Lisbon, Portugal) and counted according to the method of Utermöhl (1958), using an inverted microscope at $200 \mathrm{X} / 400 \times$ magnification. The algae were identified to the genus level, according to the method of Bourrelly $(1966,1968,1970)$.

As the highest precipitation in this region occurs between October to March, the samples were grouped in four distinct periods, as follows: (i) October 2000-March 2001 (Winter 2000/2001); (ii) April 2001-September 2001 
(Summer 2001); (iii) October 2001-March 2002 (Winter 2001/2002); and (iv) April 2002-September 2002 (Summer 2002). To determine whether or not the mean values of TP, $\mathrm{SRP}, \mathrm{N}_{-} \mathrm{NO}_{3}, \mathrm{~N}_{-} \mathrm{NH}_{4}, \mathrm{~N}-\mathrm{NH}_{3}, \mathrm{DO}$, conductivity, $\mathrm{pH}$ and water transparency were influenced by precipitation variation, a covariance analysis (ANCOVA) was carried out. This analysis also was used to test the influence of the environmental variables mentioned above on the increase in Anabaena densities and to assess whether or not the presence of this alga had some impact on the crustacean zooplankton assemblage composition. Cluster analysis (UPGMA method, Euclidean distance measure) was performed on $\log (\mathrm{x}+1)$ transformed abundance data of the most representative phytoplankton and zooplankton taxa to assess any differences between seasonal periods for species abundance. For the purpose of statistical analyses, pennate diatoms (except Asterionella formosa and Fragilaria sp.) were retained in a single category as each taxon was present in low densities.

Table 1. Mean \pm standard deviation of environmental variables in Azibo Reservoir

\begin{tabular}{|c|c|c|c|c|}
\hline Variable & Winter 2000-2001 & Winter 2001-2002 & Summer 2001 & Summer 2002 \\
\hline Water transparency $(\mathrm{m})$ & $3.2 \pm 1.7$ & $2.9 \pm 0.6$ & $4.3 \pm 0.8$ & $4.2 \pm 1.6$ \\
\hline \multicolumn{5}{|l|}{ Water temperature $\left({ }^{\circ} \mathrm{C}\right)$} \\
\hline Surface & $11.4 \pm 3.1$ & $11.0 \pm 4.3$ & $21.1 \pm 2.9$ & $19.7 \pm 4.1$ \\
\hline Mid-water column & $11.4 \pm 3.1$ & $11.0 \pm 4.3$ & $19.6 \pm 3.7$ & $20.6 \pm 1.7$ \\
\hline Bottom & $11.4 \pm 3.1$ & $11.0 \pm 4.3$ & $11.7 \pm 1.1$ & $9.9 \pm 1.3$ \\
\hline \multicolumn{5}{|l|}{ Dissolved oxygen (mg L-1) } \\
\hline Surface & $8.9 \pm 1.3$ & $8.6 \pm 0.7$ & $9.4 \pm 1.4$ & $8.4 \pm 1.0$ \\
\hline Mid-water column & $8.9 \pm 1.3$ & $8.6 \pm 0.7$ & $8.6 \pm 1.5$ & $8.1 \pm 1.1$ \\
\hline Bottom & $8.9 \pm 1.3$ & $8.6 \pm 0.7$ & $1.1 \pm 1.7$ & $2.2 \pm 1.3$ \\
\hline \multicolumn{5}{|l|}{ Conductivity $\left(\mathrm{mS} \mathrm{cm}^{-1}\right)$} \\
\hline Surface & $57.0 \pm 11.5$ & $49.6 \pm 5.5$ & $60.6 \pm 5.6$ & $66.2 \pm 8.5$ \\
\hline Mid-water column & $57.0 \pm 11.5$ & $49.6 \pm 5.5$ & $60.3 \pm 6.1$ & $68.0 \pm 4.7$ \\
\hline Bottom & $57.0 \pm 11.5$ & $49.6 \pm 5.5$ & $52.7 \pm 3.1$ & $60.5 \pm 8.9$ \\
\hline \multicolumn{5}{|l|}{$\mathrm{pH}$} \\
\hline Surface & $6.6-7.4$ & $6.9-8.4$ & $7.7-8.1$ & $6.6-7.4$ \\
\hline Mid-water column & $6.6-7.4$ & $6.9-8.4$ & $7.9-8.5$ & $7.5-7.8$ \\
\hline Bottom & $6.6-7.4$ & $6.9-8.4$ & $7.0-8.1$ & $6.2-7.4$ \\
\hline \multicolumn{5}{|l|}{$\mathrm{N}-\mathrm{NO}_{3}\left(\mathrm{mg} \mathrm{L}^{-1}\right)$} \\
\hline Surface & $10.4 \pm 4.2$ & $8.6 \pm 7.5$ & $2.6 \pm 2.4$ & $0.3 \pm 0.2$ \\
\hline Mid-water column & - & - & $2.3 \pm 2.2$ & $0.1 \pm 0.1$ \\
\hline Bottom & - & - & $1.7 \pm 2.4$ & $0.5 \pm 0.6$ \\
\hline \multicolumn{5}{|l|}{$\mathrm{N}-\mathrm{NH}_{4}\left(\mathrm{mg} \mathrm{L}^{-1}\right)$} \\
\hline Surface & $0.01 \pm 0.03$ & 0.0 & $0.01 \pm 0.03$ & $0.7 \pm 1.5$ \\
\hline Mid-water column & - & - & 0.0 & $0.1 \pm 0.1$ \\
\hline Bottom & - & - & 0.0 & $0.5 \pm 0.6$ \\
\hline \multicolumn{5}{|l|}{$\mathrm{TP}\left(\mathrm{mg} \mathrm{L}^{-1}\right)$} \\
\hline Surface & $64.4 \pm 23.8$ & $59.8 \pm 9.1$ & $68.2 \pm 17.0$ & $62.5 \pm 7.8$ \\
\hline Mid-water column & - & - & $78.9 \pm 29.6$ & $78.5 \pm 17.81$ \\
\hline Bottom & - & - & $120.5 \pm 33.5$ & $93.2 \pm 32.6$ \\
\hline \multicolumn{5}{|l|}{$\operatorname{SRP}\left(\mathrm{mg} \mathrm{L}^{-1}\right)$} \\
\hline Surface & $11.5 \pm 7.4$ & $4.1 \pm 2.4$ & $2.9 \pm 1.2$ & $7.0 \pm 4.2$ \\
\hline Mid-water column & - & - & $7.7 \pm 3.2$ & $13.4 \pm 5.3$ \\
\hline Bottom & - & - & $8.8 \pm 3.0$ & $17.3 \pm 7.7$ \\
\hline \multicolumn{5}{|l|}{ Chlorophyll a (mg L-1) } \\
\hline Integrated sample & $2.1 \pm 0.9$ & $3.7 \pm 1.9$ & $1.2 \pm 0.5$ & $1.0 \pm 0.5$ \\
\hline
\end{tabular}

Minimum-maximum range is shown for $\mathrm{pH}$. During the winter, nutrient concentrations were determined only at the surface.

$\mathrm{N}-\mathrm{NO}_{3}$, nitrate; $\mathrm{N}-\mathrm{NH}_{4}$, ammonium ion; TP, total phosphorus; SRP, soluble reactive phosphorus. 
All statistical analyses were performed using the statistical programme SYSTAT 8.0 (SPSS, Chicago, Illinois, USA).

\section{RESULTS}

\section{Environmental variables}

The total precipitation recorded between October 2000 March 2001 was $1482 \mathrm{~mm}$. In contrast, the total precipitation between October 2001-March 2002 was $424 \mathrm{~mm}$ (Agroclima-ESAB, unpubl. data, 2000-2002). Thus, the winter 2000/2001 period was considered a 'wet' winter, whereas the winter $2001 / 2002$ period was a 'dry' one. The data concerning $\mathrm{N}_{-} \mathrm{NH}_{3}$ are not shown because this variable was below detection in most samples.

Significant differences among seasons in which precipitation was considered as a covariate were found only for conductivity $(F=10.45, P<0.001$ at the surface; $\mathrm{F}=7.70, P<0.05$ at mid-water column; $\mathrm{F}=15.45, P<0.001$ at the bottom) and temperature $(F=13.49, P<0.001$ at the surface; $\mathrm{F}=10.94, P<0.001$ at mid-water column). Despite the distinct quantities of precipitation, the mean values of the above-noted environmental variables were generally similar in both winters and summers (Table 1). In contrast, the maxima and minima of some environmental parameters differed between winters. In fact, during the winter 2000/2001 period, the TP and SRP concentrations reached their maximum values (102.8

(a)

$2000 / 2001$

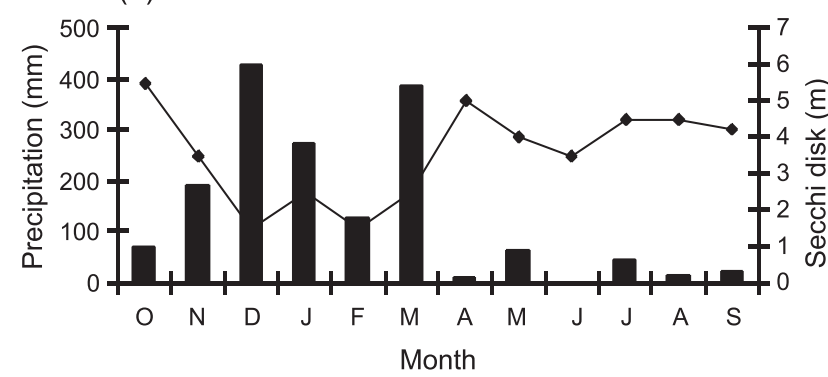

(c)

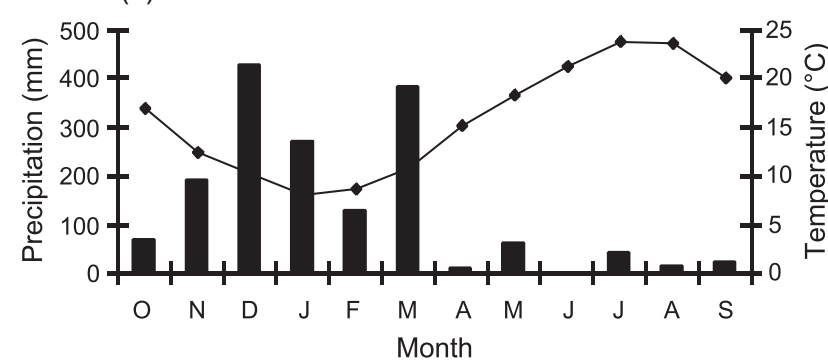

and $23.9 \mu \mathrm{g} \mathrm{L}^{-1}$, respectively), whereas the water transparency was at a minimum value $(1.5 \mathrm{~m})$. During the summer 2001 and summer 2002 periods, the minimum and maximum values of these variables were similar (Figs 2 and 3).

\section{Phytoplankton composition and abundance}

Among all the algae observed in Azibo Reservoir (Table 2), the most common were:

1. Chlorophyceae: Monoraphidium, Chlamydomonas-like cells, Scenedesmus, Crucigenia, Tetraedron, Oocystis, Paulschulzia and Cosmarium.

2. Bacillariophyceae: Asterionella, Fragilaria and Cyclotella.

3. Chrysophyceae: Dinobryon.

4. Cyanophyceae: Anabaena.

5. Cryptophyceae: Cryptomonas.

6. Dinophyceae: Ceratium.

Cluster analysis (Fig. 4a) performed on the relative abundance of algae (Table 3) indicated that the abundance and composition were similar in both summers, whereas dissimilarities were more marked between the winter periods. In fact, Ceratium, Monoraphidium and Cyclotella were dominant in the winter 2000/2001 period. However, in the winter 2001/2002 period, Anabaena became dominant between October and December 2001. Concomitant with the Anabaena dominance, a sudden depletion in the $\mathrm{N}-\mathrm{NO}_{3}$

(b)

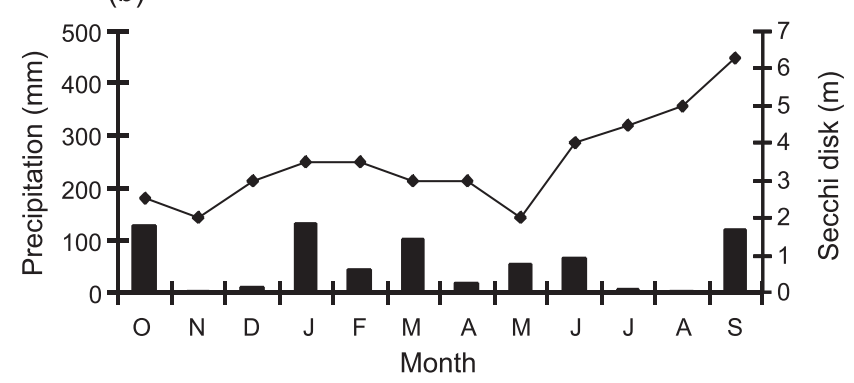

(d)

$2001 / 2002$

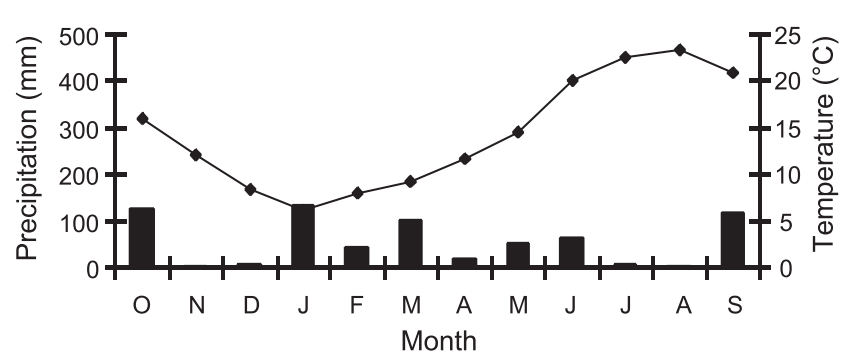

Fig. 2. (a) and (b) monthly variation of Secchi disk transparency, and (c) and (d) monthly variation of surface water temperature, with precipitation during the period of study in Azibo Reservoir. (a) and (c) correspond to the wet year while (b) and (d) correspond to the following dry year. - precipitation; $\bullet$, Secchi disk transparency (a) and (b), and temperature (c) and (d). O, October; N, November; D, December, J, January; F, February; M, March; A, April; M, May; J, June; J, July; A, August; S, September. 
concentration occurred, whereas the SRP values were almost unchanged (Fig. 5). However, ANCOVA results indicated that temperature $(F=5.50, P<0.05)$, conductivity $(F=8.78, P<0.05)$ and precipitation $(F=11.79, P<0.05)$ contributed in a synergistic way to the high density of this alga recorded in the winter 2001/2002 period. The presence of Anabaena also influenced Cyclotella abundance $(F=7.79, P<0.05)$. The highest chl $a$ concentrations were obtained in the winter during both years. During these periods, the taxa composed of large individuals were more abundant (e.g. Ceratium, Anabaena). However, taxa composed of small individuals were dominant in the phytoplankton community during both summers.

\section{Zooplankton composition and abundance}

From all zooplanktonic species found in Azibo Reservoir (Table 2), only the most abundant were considered in this study. The most abundant species were the cladocerans Daphnia longispina, Ceriodaphnia pulchella, Bosmina longirostris and Diaphanosoma brachyurum, and copepods Copidodiaptomus numidicus, Acanthocyclops robustus and their nauplii. Cluster analysis results (Fig. 4b) performed on species relative abundance (Table 4) separated the winter 2000/2001, summer 2001 and summer 2002 periods from the winter $2001 / 2002$ period. In fact, during the latter winter, coincidentally with Anabaena dominance, nauplii abundance increased, whereas Ceriodaphnia decreased.
Based on ANCOVA results, the presence of Anabaena influenced the abundance of Ceriodaphnia ( $F=11.34$, $P<0.05)$ and nauplii $(F=7.45, P<0.05)$. No significant differences among seasons were found for the other taxa when Anabaena was considered as covariate.

\section{DISCUSSION}

Except for conductivity and temperature, the mean values of environmental variables were similar in both years. However, extreme values (maximum and minimum) differed between the 2001 and 2002 winter ranges. The maximum values for TP, SRP and winter temperature, and the minimum transparency value, were recorded in the wet winter (Figs 2 and 3). Similar results were obtained by authors studying reservoirs located in other regions influenced by the Mediterranean climate (Armengol et al. 1994, 1999; Soria et al. 2000) or in other regions subjected to extensive dry and wet periods (Chalar \& Tundisi 1999). Thus, the analysis of the mean values of environmental variables does not provide a good estimation of the impacts of rainfall on reservoir limnology. In fact, one effect of precipitation (i.e. large quantities of particles in the water column) was only detected during short periods of time (Geraldes, pers. obs., 2001). This could be explained by such phenomena as: (i) the occurrence of sedimentation/ retention in periods of less turbulence (Boström et al. 1988; Chalar \& Tundisi 1999); (ii) the reduction of external loads

(b)

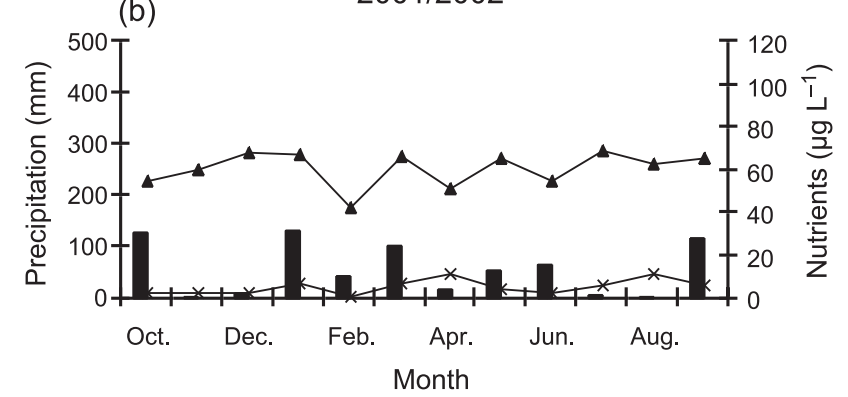

(d) (c)

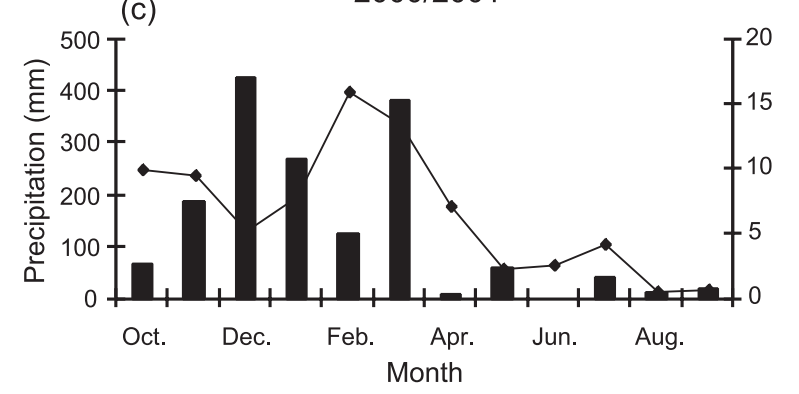

$2000 / 2001$

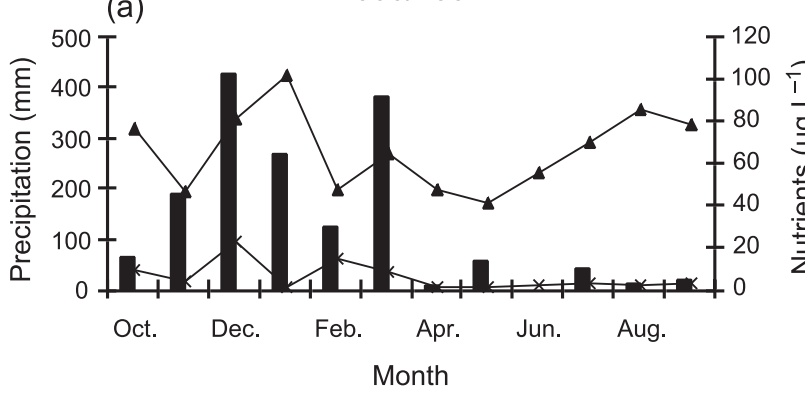

$2000 / 2001$

Fig. 3. Monthly variation of nutrients with precipitation during the period of study in Azibo Reservoir: (a) total phosphorus and soluble

reactive phosphorus during the wet year, and (b) the following dry year, (c) nitrate during the wet year, and (d) the following dry year. $\mathbf{\square}$ precipitation; $\boldsymbol{\Lambda}$, total phosphorus; $\times$, soluble reactive phosphorus; $\bullet$, nitrate.

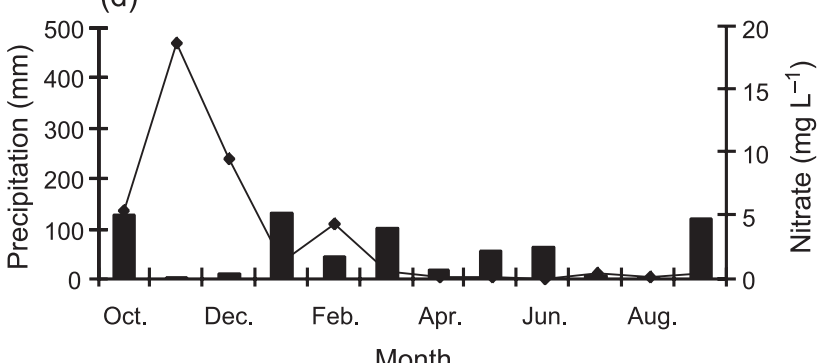


Table 2. Composition of phytoplankton and zooplankton communities in Azibo Reservoir between October 2000 and September 2002

\begin{tabular}{|c|c|}
\hline Phytoplankton & Zooplankton \\
\hline Chlorophyceae & Rotifera \\
\hline Botryococcus & Asplanchna priodonta \\
\hline Chlamydomonas & Collotheca \\
\hline Closterium & Collotheca mutabilis \\
\hline Cosmarium & Conochilus \\
\hline Crucigenia & Filinia \\
\hline Dictyosphaerium & Gastropus \\
\hline Gonium & Hexarthra \\
\hline Micrasterias & Keratella cochlearis \\
\hline Monoraphidium & Keratella quadrata \\
\hline Paulschulzia & Ploesoma \\
\hline Scenedesmus & Polyarthra \\
\hline Selenastrum & Pompholix sulcata \\
\hline Staurastrum & Testudinella \\
\hline Staurodesmus & Trichotria \\
\hline \multicolumn{2}{|l|}{ Tetraedron } \\
\hline \multicolumn{2}{|l|}{ Volvox } \\
\hline Bacillarophyceae & Cladocera \\
\hline Amphora & Alona costata \\
\hline Asterionella formosa & Alona rectangula \\
\hline Aulacoseira & Alona quadrangularis \\
\hline Cocconeis & Bosmina longirostris \\
\hline Craticula & Ceriodaphnia pulchella \\
\hline Cyclotella ocellata & Chydorus sphaericus \\
\hline Cymbella & Daphnia longispina \\
\hline Fragilaria & Daphnia pulex \\
\hline Gomphonema & Diaphanosoma brachyurum \\
\hline \multicolumn{2}{|l|}{ Gyrosigma } \\
\hline \multicolumn{2}{|l|}{ Navicula } \\
\hline \multicolumn{2}{|l|}{ Nitzschia } \\
\hline \multicolumn{2}{|l|}{ Tabellaria } \\
\hline Cyanophyceae & Copepoda \\
\hline Anabaena flos-aquae & Acanthocyclops robustus \\
\hline Chroococcus & Copidodiaptomus numidicus \\
\hline Merismopedia & Nauplii \\
\hline \multicolumn{2}{|l|}{ Oscillatoria } \\
\hline \multicolumn{2}{|l|}{ Dinophyceae } \\
\hline \multicolumn{2}{|l|}{ Ceratium hirundinella } \\
\hline \multicolumn{2}{|l|}{ Gymnodinium } \\
\hline \multicolumn{2}{|l|}{ Peridinium } \\
\hline \multicolumn{2}{|l|}{ Euglenophyceae } \\
\hline \multicolumn{2}{|l|}{ Phacus } \\
\hline \multicolumn{2}{|l|}{ Trachelomonas } \\
\hline \multicolumn{2}{|l|}{ Cryptophyceae } \\
\hline \multicolumn{2}{|l|}{ Cryptomonas } \\
\hline \multicolumn{2}{|l|}{ Chrysophyceae } \\
\hline \multicolumn{2}{|l|}{ Dinobryon } \\
\hline Mallomonas & \\
\hline
\end{tabular}

at the end of the rainfall period (Johnes et al. 1996; Barbosa \& Hvitved-Jacobsen 1999; McGarrigle et al. 2000; Rybak 2000; Miranda \& Matvienko 2003); and/or (iii) the intensity of recycling by biotic components (Catalan \& Fee 1994; Reynolds et al. 1998). Despite the lack of data concerning the intensity of those processes in Azibo Reservoir, one could expect that the observed changes were related to a balance between the above-mentioned processes (sedimentation, nutrient loads, recycling), similar to what happens in other reservoirs.

In water samples obtained downstream of one of Azibo Reservoir's tributaries during the wet winter, Geraldes and Boavida (2003) noticed that the TP concentrations were $103 \mu \mathrm{g} \mathrm{L}^{-1}$ at the beginning of the rainfall period, decreas-

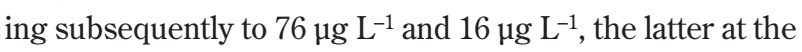

(a)

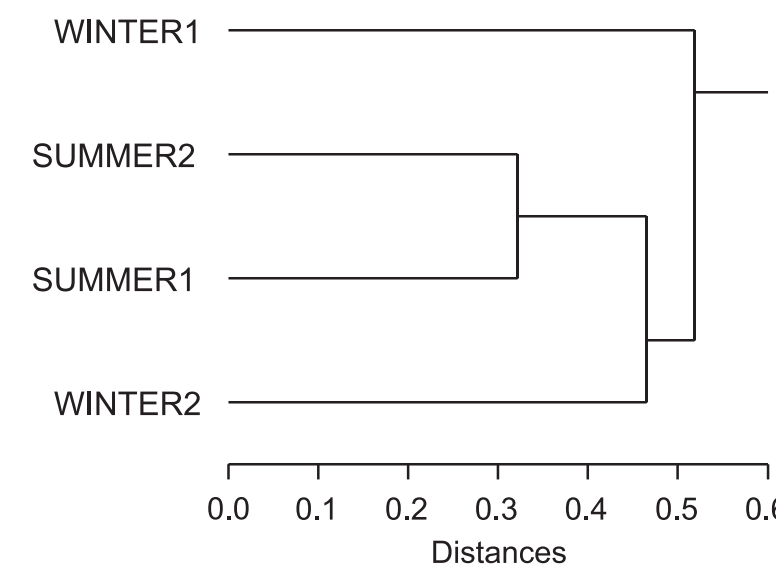

(b)

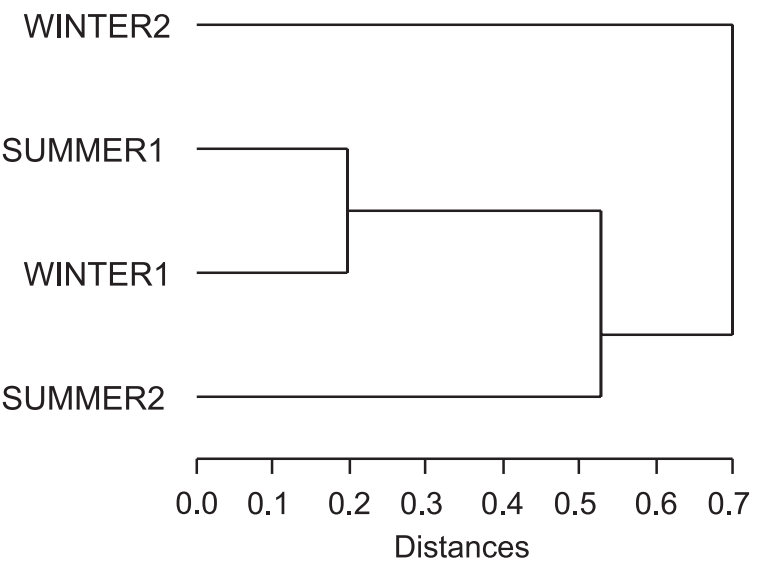

Fig. 4. Cluster analysis diagram depicting periods defined according to (a) phytoplankton and (b) zooplankton composition and abundance during the period of study in Azibo Reservoir. Winter1, Winter 2000/2001 samples; Summer1, Summer 2001 samples; Winter2, Winter 2001/2002 samples; Summer2, Summer 2002 samples. 
end of the precipitation period. The TP concentrations in the reservoir varied concomitantly with the trends observed downstream. Conversely, during the dry winter, the TP concentrations were much lower (around $70 \mu \mathrm{g} \mathrm{L}^{-1}$ ) at the beginning of the rainfall period. At the end of the

(a)

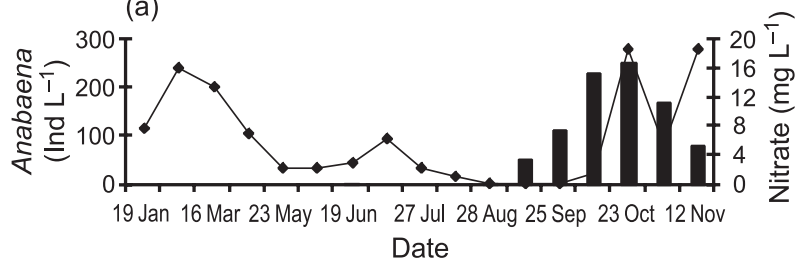

(b)

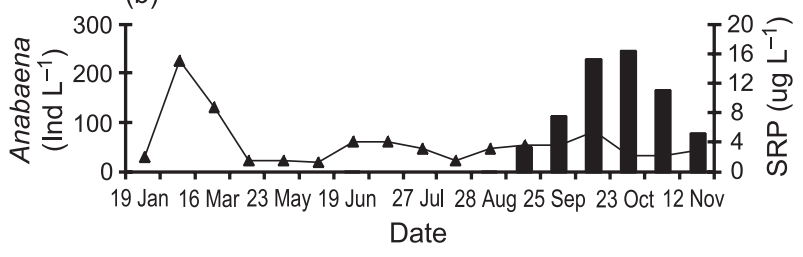

Fig. 5. Variation of (a) nitrate and (b) soluble reactive phosphorus (SRP) surface water concentrations during 2001 in Azibo Reservoir.

$\mathbf{\square}$, Anabaena densities; $\bullet$, nitrate; $\boldsymbol{\Lambda}$, soluble reactive phosphorus. rain period, the TP concentrations were similar to those obtained during the wet winter, but the TP concentrations did not change much in the reservoir. The estimated potential nutrient loads generated by anthropogenic activities in the drainage basin and the reservoir surroundings were $\approx 243275 \mathrm{~kg}$ of $\mathrm{N}$ and $116956 \mathrm{~kg}$ of $\mathrm{P}$ per year (Geraldes \& Boavida 2003). Despite the capacity of the reservoir, which is large enough to dilute those loads, temporary increases in nutrient concentrations in the water column occurred during intense rainfall events. As is evidenced by the data mentioned above, the nutrient inputs progressively decreased until the end of the rainfall event. However, these values can change from one year to another as a function of rain quantity and intensity. Furthermore, because of the existence of numerous buffer areas in the reservoir drainage basin (e.g. woodlands, riparian vegetation) the actual nutrient loading can be much lower than the estimated, even during wet years. During dry periods, the particles transported by wind from surrounding areas can be an important source of $\mathrm{P}$, influencing concentrations of this nutrient in the water column during both summers and also during the dry winter (e.g. Cole et al. 1990). Those particles were often observed at the

Table 3. The most abundant phytoplankton genera in Azibo Reservoir, quantified using the mean \pm standard deviation of seasonal relative abundances

\begin{tabular}{|c|c|c|c|c|}
\hline Phytoplankton & Winter 2000-2001 & Winter 2001-2002 & Summer 2001 & Summer 2002 \\
\hline \multicolumn{5}{|l|}{ Chlorophyceae } \\
\hline Chlamydomonas & $1.4 \pm 2.1$ & $3.8 \pm 6.5$ & $13.8 \pm 29.6$ & $13.0 \pm 25.9$ \\
\hline Cosmarium & $0.4 \pm 0.9$ & $0.5 \pm 0.5$ & $0.6 \pm 1.7$ & $0.1 \pm 0.1$ \\
\hline Crucigenia & $2.8 \pm 3.2$ & $0.7 \pm 0.4$ & $2.7 \pm 6.5$ & $0.2 \pm 0.5$ \\
\hline Monoraphidium & $16.6 \pm 27.2$ & $0.1 \pm 0.2$ & $0.7 \pm 1.6$ & $0.1 \pm 0.2$ \\
\hline Oocystis & $0.1 \pm 0.2$ & $1.6 \pm 2.7$ & $0.8 \pm 2.0$ & $0.1 \pm 0.1$ \\
\hline Paulschulzia & $1.5 \pm 1.7$ & $17.2 \pm 23.6$ & $0.9 \pm 2.8$ & $11.3 \pm 28.4$ \\
\hline Scenedesmus & $0.4 \pm 0.4$ & $1.1 \pm 1.2$ & $0.6 \pm 0.6$ & $0.6 \pm 0.4$ \\
\hline Tetraedron spp. & 0.0 & $0.5 \pm 0.4$ & $0.2 \pm 0.3$ & $0.2 \pm 0.2$ \\
\hline \multicolumn{5}{|l|}{ Bacillariophyceae } \\
\hline Cyclotella & $31.1 \pm 21.5$ & $16.6 \pm 19.2$ & $59.9 \pm 37.2$ & $61.7 \pm 35.4$ \\
\hline Asterionella & $9.7 \pm 12.7$ & $2.2 \pm 2.0$ & $0.3 \pm 0.5$ & $0.6 \pm 1.2$ \\
\hline Fragilaria & $2.4 \pm 2.7$ & $3.2 \pm 6.3$ & $3.7 \pm 9.9$ & $0.1 \pm 0.1$ \\
\hline Other pennate diatoms & $4.4 \pm 6.0$ & $1.1 \pm 1.6$ & $0.1 \pm 0.1$ & $0.4 \pm 0.5$ \\
\hline \multicolumn{5}{|l|}{ Cryptophyceae } \\
\hline Cryptomonas & $6.5 \pm 8.1$ & $9.6 \pm 6.4$ & $9.8 \pm 16.4$ & $8.2 \pm 10.0$ \\
\hline \multicolumn{5}{|l|}{ Cyanophyceae } \\
\hline Anabaena & $4.5 \pm 6.0$ & $41.4 \pm 30.1$ & $3.4 \pm 7.2$ & $0.2 \pm 0.3$ \\
\hline \multicolumn{5}{|l|}{ Dinophyceae } \\
\hline Ceratium & $20.2 \pm 13.9$ & $0.1 \pm 0.1$ & $4.5 \pm 9.0$ & $3.1 \pm 5.1$ \\
\hline \multicolumn{5}{|l|}{ Chrysophyceae } \\
\hline Dinobryon & 0.0 & $0.3 \pm 0.4$ & 0.0 & $0.2 \pm 0.3$ \\
\hline
\end{tabular}


Table 4. The most common zooplankton species in Azibo Reservoir, quantified using the mean \pm standard deviation of seasonal relative abundances

\begin{tabular}{lcccc}
\hline Zooplankton & Winter 2000-2001 & Winter 2001-2002 & Summer 2001 & Summer 2002 \\
\hline Cladocera & & & & $1.6 \pm 1.9$ \\
$\quad$ Bosmina longirostris & $1.2 \pm 1.2$ & $3.3 \pm 1.4$ & $1.8 \pm 1.0$ & $25.9 \pm 24.7$ \\
$\quad$ Ceriodaphnia pulchella & $25.0 \pm 28.5$ & $10.1 \pm 17.0$ & $38.3 \pm 33.8$ & $5.3 \pm 10.4$ \\
Diaphanosoma brachyurum & 0.0 & 0.0 & $3.2 \pm 5.1$ & $5.5 \pm 7.3$ \\
$\quad$ Daphnia longispina & $12.9 \pm 8.7$ & $13.2 \pm 10.7$ & $9.4 \pm 19.0$ & $0.9 \pm 0.9$ \\
Copepoda & $0.9 \pm 1.2$ & $3.9 \pm 3.7$ & $1.7 \pm 1.5$ & $43.6 \pm 13.9$ \\
$\quad$ Acanthocyclops robustus & $44.1 \pm 16.6$ & $31.1 \pm 19.1$ & $31.5 \pm 20.4$ & $17.9 \pm 13.5$ \\
$\quad$ Copidodiaptomus numidicus & $15.9 \pm 23.1$ & $38.4 \pm 15.3$ & $14.1 \pm 11.0$ & \\
Nauplii & & & & \\
\hline
\end{tabular}

water surface of this reservoir, especially during the late spring and summer months, and consisted of terrestrial insects and plant fragments (Geraldes, pers. obs., 20012002).

The most remarkable change in phytoplankton composition was the dominance of Anabaena during October December 2001 (dry winter). A relevant question is why did this alga become dominant during this period? Vasconcelos (1990) previously recorded the dominance of Anabaena during an extensive dry period for this reservoir, which also occurred subsequent to a wet winter. Similar patterns were described by other authors (e.g. Ahn et al. 2002). The conditions created by the subsequent dry periods (summer 2001 and winter 2001/2002) provided the ecological optimum for Anabaena dominance. According to Reynolds (1998), the dominance of a particular algal species is the result of a stochastic combination of environmental variables. Anabaena is not only favoured by $\mathrm{N}^{-\mathrm{NO}_{3}}$ depletion (Sakamoto \& Okino 2000), but also by more stable environmental conditions, such as absence of water turbulence, larger water retention time (Reynolds et al. 2002) and higher irradiance (Ahn et al. 2002). This ecological optimum was achieved in Azibo Reservoir during the dry period in this study, consequently conferring an adaptive advantage to Anabaena over Cyclotella and Ceratium, the latter being the dominant genera during the wet winter. Even after the increase in $\mathrm{N}^{-\mathrm{NO}_{3}}$ subsequent to stratification disruption, Anabaena densities only decreased when the water temperature dropped below $10^{\circ} \mathrm{C}$ and after the precipitation events recorded in January 2002. At the beginning of the winter 2002/2003 period, Anabaena was again detected in very low densities. As a result of high water turbulence generated by the heavy precipitation that occurred during this period, however, Anabaena did not reach the high densities recorded during the winter 2000/2001 period. In fact, Anabaena was not detected from November 2002 onwards.

The influence of Anabaena dominance on the crustacean zooplankton abundance is well known (e.g. Lampert \& Sommer 1997). In fact, zooplankton composition frequently changes under the influence of the alga, and copepods and rotifers often replace cladocerans. The results of covariance analysis indicated that the decrease in Ceriodaphnia and the increase in nauplii abundance in the dry winter are a consequence of the presence of this cyanobacterium. However, Ceriodaphnia could also have been affected by the slightly lower temperatures recorded in the dry winter (e.g. Lynch 1978). Other abiotic or biotic interactions beyond the scope of the present paper also could have influenced the abundance of crustacean zooplanktonic species in the reservoir.

During the years of study, the observed changes in nutrient concentrations, as well as in Anabaena and crustacean zooplankton abundance, were related, at least partially, to variations in rainfall intensity. It is acknowledged, however, that this study is a preliminary assessment of the reservoir. It will be necessary to obtain a longer data series, enabling a simultaneous analysis of intra- and interannual ecosystem changes in order to fully understand the ways in which variations in precipitation can influence reservoir ecology. Such data will be crucial to develop correct management measures (e.g. development and restoration of buffer areas, such as woodlands and riparian woods) and to minimize and predict the negative impacts of extreme precipitation and nutrient loading on ecosystem health and, consequently, on water quality.

\section{ACKNOWLEDGEMENTS}

This study was supported by Fundação para a Ciência e a Tecnologia, Portugal (Project Praxis XXI/C/BIA/11012/ 98) and a doctoral fellowship awarded to A. M. Geraldes 
(4/5.3/PRODEP/2000) for part of the study. A. Ribeiro, A. Teixeira, N. Marcos, A. Saraiva and S. Branco assisted in field work. M. J. Caramujo kindly identified the copepods as did S. Almeida and A. J. Calado for diatoms and green algae. Agroclima-ESAB provided precipitation data. The authors are grateful to two anonymous referees who helped to improve an earlier version of the manuscript.

\section{REFERENCES}

Ahn C. Y., Chung A. S. \& Oh H. M. (2002) Rainfall, phycocyanin, and $\mathrm{N}$ : P ratios related to cyanobacterial blooms in a Korean large reservoir. Hydrobiologia 474, 117-24.

American Public Health Association (1989) Standard Methods for the Examination of Water and Wastewater. American Public Health Association, Washington D. C., USA.

Armengol J., Garcia J. C., Comerma M. et al.(1999) Longitudinal processes in canyon type reservoirs: The case of Sau (N. E. Spain). In: Theoretical Reservoir Ecology (eds J. G. Tundisi \& M. Straškraba) pp. 313-45. International Institute of Ecology, Brazilian Academy of Sciences, São Carlos.

Armengol J., Toja J. \& Vidal A. (1994) Seasonal rhythm and secular changes in Spanish reservoirs. In: Limnology Now: a Paradigm of Planetary Problems (ed. R. Margalef) pp. 237-53. Elsevier Science B. V., Amsterdam.

Barbosa A. E. \& Hvitved-Jacobsen T. (1999) Highway runoff and potential for removal of heavy metals in an infiltration pond in Portugal. Sci. Tot. Environ. 235, 151-9.

Boström B., Persson G. \& Broberg B. (1988) Bioavailability of different phosphorus forms in freshwater systems. Hydrobiologia 170, 21-34.

Bourrelly P. (1966) Les Algues d'Eau Douce. I: les Algues Vertes. Editions N. Boubée, Paris.

Bourrelly P. (1968) Les Algues d'Eau Douce. II: les Algues Jaunes et Brunes. Editions N. Boubée, Paris.

Bourrelly P. (1970) Les Algues d'Eau Douce. III: les Algues Bleues et Rouges. Editions N. Boubée, Paris.

Catalan J. \& Fee E. J. (1994) Interannual variability in limnic ecosystems: Origin, patterns and predictability. In: Limnology Now: a Paradigm of Planetary Problems (ed. R. Margalef) pp. 81-97. Elsevier Science B. V., Amsterdam.

Chalar G. \& Tundisi J. G. (1999) Main processes in the water column determined by wind and rainfall at Lobo (Broa) Reservoir. Implications for phosphorus cycling. In: Theoretical Reservoir Ecology (eds J. G. Tundisi \& M. Straškraba) pp. 53-65. International Institute of Ecology, Brazilian Academy of Sciences, São Carlos.
Cole J. J., Caraco N. F. \& Likens G. E. (1990) Short-range atmospheric transport: A significant source of phosphorus to an oligotrophic lake. Limnol. Oceanogr. 35, 1230-7.

Dussart B. (1969) Les Copepodes des Eaux Continentales d'Europe Occidentale - Tome II - Cyclopoïdes et Biologie. Editions N. Boubée et vie, Paris.

Geraldes A. M. \& Boavida M. J. (2003) Distinct age and landscape influence on two reservoirs under the same climate. Hydrobiologia 504, 277-88.

Institute of Meteorology-Portugal (2001) Informação climática. Available at URL: http://www.meteo.pt. Accessed 5 January 2003.

Johnes P., Moss B. \& Phillips G. (1996) The determination of total nitrogen and total phosphorus concentrations in freshwater from land use, stock headage and population data: Testing of a model for use in conservation and water quality management. Freshwat. Biol. 36, 451-73.

Lampert W. \& Sommer U. (1997) Limnoecology - the Ecology of Lakes and Streams. Oxford University Press, New York.

Lynch M. (1978) Complex interactions between natural coexploiters - Daphnia and Ceriodaphnia. Ecology 59, 552-64.

McGarrigle M. L., Hallisey R., Donnelly K. \& Kilmartin L. (2000) Trends in phosphorus loading to Lough Conn, Co. Mayo, Ireland. Verh. Internat. Verein. Limnol. 27, 2642-7.

Miranda S. A. \& Matvienko B. (2003) Rain and groundwater as phosphorus sources of a small reservoir. Lakes Reserv.: Res. Manage. 8, 27-30.

Murphy J. \& Riley J. P. (1962) A modified single solution method for the determination of phosphate in natural waters. Anal. Chim. Acta 27, 31-6.

Reynolds C. S. (1998) What factors influence the species composition of phytoplankton in lakes of different trophic status? Hydrobiologia 369/370, 11-26.

Reynolds C. S., Desortová B. \& Rosendorf P. (1998) Modelling the responses of lakes to day-to-day changes in weather. In: Management of Lakes and Reservoirs during Global Climate Change (eds D. G. George, J. C. Jones, P. Puncochar, C. S. Reynolds \& D. W. Sutcliffe) pp. 289-95. Kluwer Academic Publishers, Amsterdam.

Reynolds C. S., Huszar V., Kruk C., Naselli-Flores L. \& Melo S. (2002) Towards a functional classification of the freshwater plankton. J. Plankton Res. 24, 417-28.

Rybak J. (2000) Long-term and seasonal dynamics of nutrient export rates from lake watersheds of diversi- 
fied land cover pattern. Verh. Internat. Verein. Limnol. 27, 3132-6.

Sakamoto M. \& Okino T. (2000) Self-regulation of cyanobacterial blooms in eutrophic lake. Verh. Internat. Verein. Limnol. 27, 1243-9.

Scourfield I. S. O. \& Harding J. P. (1966) A Key to British Freshwater Cladocera. Freshwater Biological Association, Ambleside.

Soria J. M., Vicente E. \& Miracle M. R. (2000) The influence of flash floods on the limnology of the
Albufera of Valencia Lagoon (Spain). Verh. Internat. Verein. Limnol. 27, 2232-5.

Utermöhl H. (1958) Zur vervolkommnung der quantitativen phytoplankton methodik. Mitt. Int. Verein. Limnol. 9, 1-38.

Vasconcelos V. M. (1990) First approach to the limnology of Azibo Reservoir (Portugal). Pub. Inst. Zool. ' Dr A. Nobre' 218, 1-21. 